551.524.35: 551.583 .14

\author{
- кртчян \\ ьвівський н ціон льний університет імені в н \\ вул. . орошенк , 41, м. ввів, 79000, кр їн \\ e-mail: alemkrt@yahoo.com
}

ро н лізов но н йсуч снішу н укову інформ цію щодо розмірів, причин, чинників т прогнозів глоб льного потепління н підст ві д них ост нньої доповіді іжурядової групи експертів з пит нь змін клім ту. підст ві порівняльного н лізу д них спостережень метеост нцій з хідних регіонів кр їни виявлено головні тенденції змін темпер турного режиму приземного ш ру повітря з ост ннє століття. роблено уз г льнений прогноз змін темпер турного режиму н н ступні десятиліття т ймовірних н слідків цих змін для природи і господ рств .

лючові слов : глоб льне потепління, п рниковий ефект, темпер турний режим, прогноз клім тичних змін.

ст нніми рок ми у світі величезну ув гу приділяють проблемі нтропогенно зумовленого глоб льного потепління, як посід є провідне місце серед усіх глоб льних екологічних проблем з ув гою, що їй приділяють н міжн родних політичних форум х, у з соб х м сової інформ ції, в діяльності впливових міжн родних природоохоронних орг ніз цій. кр їні, н відміну від більшості високорозвинутих кр їн, цій проблемі приділено порівняно менше ув ги, зокрем , м ло пр ць, у яких були б висвітлені можливі її н слідки для кр їни у зв'язку з її природними т соціоекономічними ре ліями. кож є кту льними пр ці, які містять н ліз ре льних клім тичних змін з ост нні десятиліття н підст ві д них метеоспостережень. кий н ліз, крім іншого, д сть змогу екстр полюв ти виявлені тенденції н м йбутнє.

ьогодні у світовій н уці є консенсус щодо с мого ф кту нтропогенно зумовленого глоб льного потепління, яке н кл д ється н природну клім тичну мінливість. нтенсивність розгорт ння цього явищ в м йбутньому т його можливі н слідки, проте, достеменно не відомі. ех нізм п рникового ефекту, який спричиняє це явище, був уперше обгрунтов ний ще у 1896 р. шведським хіміком в нте рреніусом.

1988 р. сесвітньою метеорологічною орг ніз цією ( ) т рогр мою 3 довкілля ( ) створено іжурядову групу експертів 3 пит нь змін клім ту ( ), з вд нням якої є оцінк ризиків змін клім ту, зумовлених техногенними чинник ми. р зі підготовлено чотири доповіді (ост ння вийшл 2007 р.), які містять н укові оцінки розмірів глоб льного потепління, його причин і чинників т прогнози щодо под льшого розгорт ння. ижче н ведемо н йв жливіші висновки, які містить ост ння доповідь [4].

н слідок діяльності людини глоб льн концентр ція 2 в земній тмосфері зросл від $0,028 \%$ в доісторичні ч си до 0,0381\% ст ном н 2006 р.: ост ннім десятиліттям ця концентр ція щорічно зрост л н $0,0002 \%$. лизько $80 \%$ зрост ння концентр ції

(C) кртчян ., 2010 
2 пов'яз не з використ нням викопного п лив, решт $20 \%$ - зі змін ми у землекористув нні (вирубув ння лісів, осушув ння боліт тощо). 3 зн чений період щороку вн слідок сп люв ння вуглеводневого п лив в тмосферу потр пляло близько 27 млрд. т 2. кщо в середньому н одного жителя пл нети прип д ло близько 4,3 т/рік, то в розр хунку н кожного мешк нця цей пок зник перевищув в 20 т/рік. одноч с, порівняно з доіндустрі льним періодом суттєво збільшився вміст в тмосфері інших п рникових г зів - мет ну (більше ніж удвічі) $\mathrm{T}$ оксиду зоту (н $20 \%$ ). г льний чистий ефект від нтропогенної діяльності з імовірністю $90 \%$ ст -

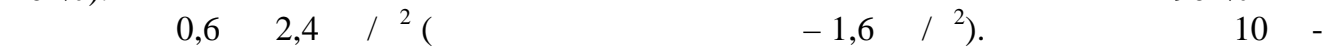
зів більше, ніж р ді ційний ефект від збільшення н дходження сонячної $\mathrm{p}$ ді ції через колив ння п р метрів земної орбіти [4].

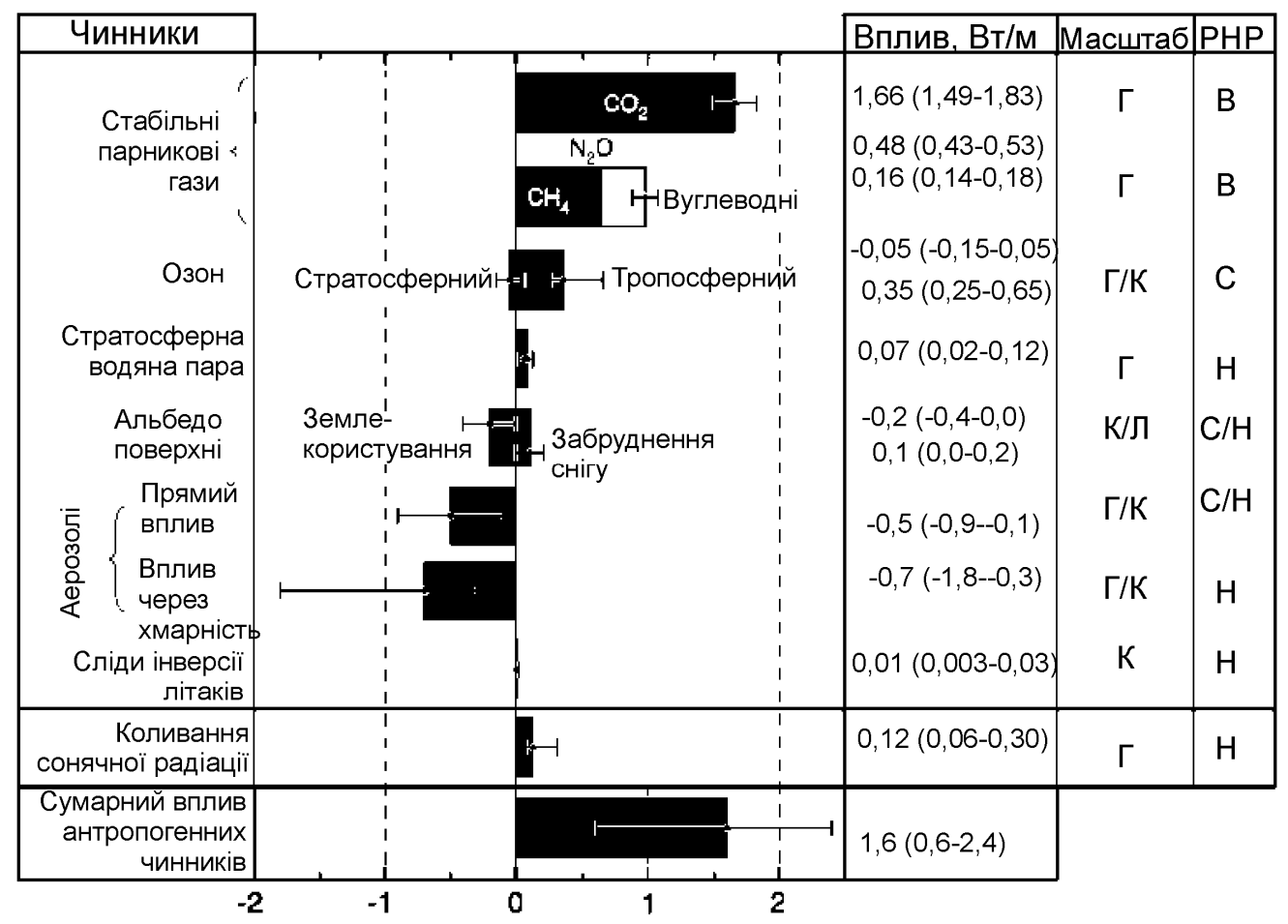

ис. 1. оловні чинники впливу н глоб льний клім т (згідно з доповіддю з 2007 р. і обочої групи [4]). сшт б прояву: - глоб льний, - континент льний, - лок льний;

- н явний рівень н укового розуміння впливу чинник н клім т: - високий, - середній,

- низький. диницями вимірюв ння впливу чинників є енергетичний вплив н р ді ційний 6 л нс емлі, т/м². інії з риск ми у другому стовбці т цифри в дужк х у третій - вірогідний інтерв л 0,9 (рівень н дійності - $90 \%$ ).

рис. 16 чимо, що н йв жливішим т н йдостовірнішим чинником впливу н клім т є нтропогенні викиди вуглекислого г зу $\mathrm{CO}_{2}$. двічі менший вплив інших п рникових г зів - мет ну, оксиду зоту т вуглеводнів. одноч с, деякі види людської діяльності охолоджують клім т. о т ких н леж ть викиди ерозолів, які зменшують 
н дходження сонячної р ді ції до земної поверхні, як безпосередньо відбив ючи іiі, т к і опосередков но, відігр ючи роль ядер конденс ції водяної п ри і збільшуючи хм рність, як , відповідно, з тримує сонячну р ді цію. плив нтропогенних ерозолів н хм рність є н йменше вивченою л нкою мех нізму глоб льного потепління, як визн ч є суттєву (у чотири р зи) н укову невизн ченість щодо кількісного розміру сум рного впливу нтропогенних чинників н клім т емлі.

йв жливішим позитивним зворотним зв'язком у мех нізмі глоб льного потепління є водян п р . о збільшення пї вмісту у повітрі призводить зрост ння вип ровув ння $з$ поверхні оке нів т морів з підвищенням темпер тури; т кож водян п р с м по собі є п рниковим г зом, який з тримує інфр червоне випромінюв ння земної поверхні, сприяючи потеплінню. $\quad$ г лом, згідно з суч сними моделями, у р зі подвоєння концентр ції $\mathrm{CO}_{2}$ порівняно $з$ доісторичним періодом, середня глоб льн приземн темпер тур підвищиться н $2,0-4,5^{\circ} \quad[4]$.

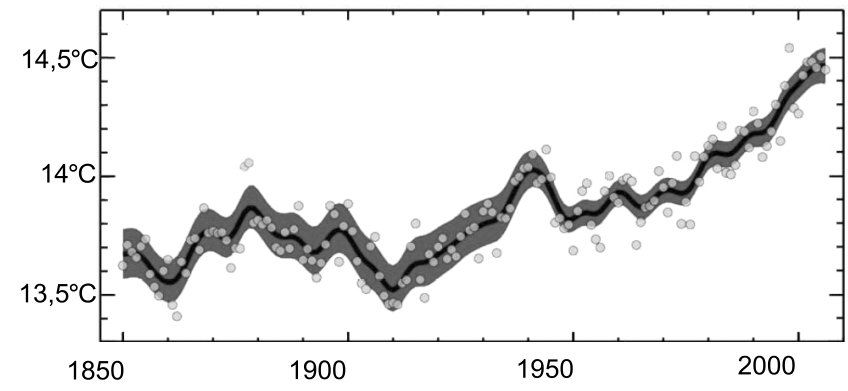

ис. 2. міни середньої глоб льної приземної темпер тури повітря (згідно з доповіддю 3 2007 p. і обочої групи іжурядової комісії зі змін клім ту [4]).

рис. 2 пок з ні зміни середньої глоб льної темпер тури повітря біля земної поверхні з ост нні 150 років. ружк ми позн чені темпер тури 3 кожен рік, чорною лінією - усереднені зн чення з дек ду, сірою смугою - вірогідний інтерв л 0,9 (у його меж х є зн чення середньодек дної темпер тури з імовірністю 0,9 , вр ховуючи похибки вимірюв нь т обчислень). ост нні 100 років (1906-2005) середня глоб льн темпер тур підвищил сь н $0,74^{\circ}$, причому н йбільше підвищення спостеріг ли від поч тку 1980-х років. дин дцять 3 дв н дцяти років з період 1995-2006 рр. потр пили до числ дв н дцяти н йтепліших років 3 результ т ми інструмент льних спостережень (з 1850 р.)

д ними супутникових вимірюв нь, від 1993 до 2003 р. рівень вітового оке ну щорічно зрост в н 3 мм, причому як ун слідок т нення льодовиків, т к і, ще більше, через терм льне розширення води (збільшення їі об'єму з підвищенням темпер тури).

гом $з$ ст. цей рівень зріс н 17 см.

міни клім ту були неодн ковими в різних регіон х емної кулі. прикл д, в рктиці з ост ннє століття підвищення темпер тур було вдвічі більшим, ніж у середньому по емній кулі. роте н йбільше підвищення темпер тури в рктиці спостеріг ли в 1930-ті роки, тоді як в 1990-ті темпи потепління т м були меншими, ніж у середньому н пл неті [4].

уттєво відрізнялись 3 регіон ми зміни в кількості тмосферних оп дів. н чно зросл кількість оп дів н сході івнічної т івденної мерики, півночі вропи, н 
півночі т сході зії. одноч с в деяких інших регіон х клім т ст в більш посушливим, зокрем , в ередземномор'і, хелі т івденній фриці. ерез підвищення темпер тури морської води т вмісту водяної п ри в тмосфері в більшості регіонів зросл ч стот сильних злив, збільшил сь ктивність тропічних циклонів у івнічній тл нтиці. роте поки що нем є свідчень перебудови великом сшт бної тмосферної циркуляції [4].

нтропогенне походження суч сних клім тичних змін підтверджене і п леоклім тичними д ними. окрем , згідно з зг д ною доповіддю, ост нні півстоліття, ймовірно, були н йтеплішими 3 ост нні 1300 років. дн к, в ост нній міжльодовиковий період (близько 125 тис. років тому) середні темпер тури в рктиці були н $3-5^{\circ}$ вищими, ніж тепер, рівень вітового оке ну, перев жно вн слідок т нення рктичної криги, перевишув в теперішній н 4-6 м. оді причиною потепління було відповідне положення земної орбіти щодо онця. історичний період н йбільш в жливими природними чинник ми клім тичних змін були зміни в н дходженні сонячної р ді ції вн слідок колив нь положення земної орбіти т вулк нічн ктивність (похолод ння вн слідок н дходження в тмосферу великої кількості вулк нічних ерозолів).

ьогодні н явні моделі, які зд тні дост тньо н дійно передб чити м йбутні зміни клім ту вн слідок нтропогенної діяльності. йдоскон лішими вв ж ють моделі глоб льної циркуляції оке ну т тмосфери (АOGCM). ередб ч ють, що моделі, які точно описують зміни клім ту в минулому, з т кою ж точністю зд тні передб чити й м йбутні зміни. гідно з д ними , у н йближчі дв десятиліття темпи підвищення глоб льної темпер тури повітря ст новитимуть $0,2 \% 10$ років. ік во, що н віть якби викиди всіх п рникових г зів р птом припинились, у н ступні дві дек ди все одно б спостеріг ли підвищення глоб льної темпер тури н $0,1 \% 10$ років, до кінця століття воно 6 ст новило $0,6^{\circ}$, через інерційність вітового оке ну. одо темпів потепління н д лі, то вони суттєво з леж тимуть від х р ктеру розвитку людської цивіліз ції в ст. огляду н це, розроблено декільк сцен ріїв дин міки викидів п рникових г зів у ст. оделі, у яких розроблено ці сцен рії, з свідчили, що від них суттєво з лежить розмір клім тичних змін н прикінці століття.

йінтенсивнішими ці зміни будуть у р зі розвитку сцен рію, який передб ч є збереження суч сного гетерогенного світу з різкими відмінностями у якості життя, продуктивності т структурі економіки між високо- т сл бкорозвинутими кр їн ми, низьким рівнем глоб ліз ції, відносною культурною т господ рською ізоляцією низки регіонів світу, низькими темп ми поширення технологічних іннов цій у кр їни третього світу. ередб ч ють, що в т кому р зі н селення світу впродовж усього ст. продовжув тиме зрост ти. ільшість моделей у вип дку втілення цього сцен рію прогнозує підвищення глоб льної темпер тури до 2100 р. н $3,5^{\circ}$, деякі моделі - більш ніж $\mathrm{H} 5^{\circ}$.

ругий сцен рій передб ч є швидке економічне зрост ння в сл бкорозвинутих кр їн х, яке супроводжув тиметься швидким поширенням суч сних технологій; у цьому p зі зменшув тиметься розрив у доход х між б г тими і бідними кр їн ми, посилюв тимуться економічні т культурні зв'язки між регіон ми. селення емлі зрост тиме до середини століття, після чого ст білізується. розвитку цього сцен рію темпи глоб льного потепління будуть дещо меншими (підвищення темпер тури - близько 2,8 H 2100 p.)

ретій сцен рій зм льовує світ, який повільно глоб лізується, глоб льн кількість н селення впродовж н ступного століття зрост тиме, технологічний прогрес сповіль- 
ниться, екологічні й соці льні проблеми вирішув тимуть н лок льному т регіон льному рівнях, без з лучення глоб льних інструментів. $\mathrm{p}$ зі ре ліз ції цього сцен рію н прикінці століття очікують підвищення глоб льної темпер тури близько $2,4^{\circ}$.

етвертий сцен рій, подібно до другого, передб ч є ст біліз цію кількості н селення емлі до середини століття, проте охоплює швидкі зміни в структурі економік більшості кр їн у бік зрост ння ролі інформ ційної економіки т сфери послуг, зменшення м тері ломісткості виробництв, впров дження чистих і ресурсоощ дних технологій. оч цей сцен рій не вр ховує впливу дод ткових спеці льних клім тичних ініці тив, т ких, як іотський протокол, з його ре ліз ції клім тичні зміни н прикінці століття будуть н йм'якішими: підвищення глоб льної темпер тури не перевищув тиме $2^{\circ}$.

оделі т кож д ють змогу передб чити підвищення рівня вітового оке ну до кінця століття вн слідок глоб льного потепління. е підвищення ст новитиме від 0,2 м у р зі ре ліз ції четвертого сцен рію до 0,4-0,5 м у вип дку ре ліз ції першого. роте досі достеменно не відомо, як поведуться у р зі суттєвого потепління льодовикові ш пки нт рктиди т ренл ндії: у вип дку швидких змін у дин міці континент льних льодовикових щитів підвищення рівня оке ну може бути суттєво більшим. ідкислення вітового оке ну через збільшення н дходження 2 може нег тивно вплинути н морські орг нізми (кор ли, р коподібні, молюски, фор мініфери), які будують свій зовнішній скелет з к льциту чи р гоніту.

уч сні моделі допом г ють т кож передб чити регіон льні відмінності у м йбутніх клім тичних змін х. г лом прогнозують, що регіон льн к ртин потепління буде незмінною порівняно з тією, що простежув л сь в минулі десятиліття. йбільшого потепління треб очікув ти н д рктикою т івнічно- хідною зією, тоді як н йменші зміни темпер тур спостеріг тимуть н д південними ч стин ми оке нів, т кож н д івнічною тл нтикою (з вдяки посл бленню ольфстріму). еред інших очікув них змін - зменшення поширення б г торічної мерзлоти, снігового покриву т морської криги, причому деякі моделі передб ч ють, що н прикінці століття івнічний ьодовитий оке н щоліт повністю очищ тиметься від криги. рост тиме потужність тропічних циклонів т сильних злив у поз тропічних р йон х. одо з г льної кількості оп дів, то н йбільше зрост ння очікують у полярних $\mathrm{p}$ йон х у зимовий період. кож кількість оп дів зросте в приекв торі льних р йон х т (в зимовий період) у помірному поясі. уттєвого зменшення кількості оп дів треб очікув ти в р йон х середземноморського клім ту. ідбув тиметься з г льне зміщення меж клім тичних поясів т зон у н прямі до полюсів.

одо відд леніших змін передб ч ють, зокрем, що в р зі, якщо середня глоб льн темпер тур перевищить теперішне зн чення н $2-4^{\circ}$, б л нс льоду у ренл ндському льодовиковому щиті ст не нег тивним. продовж тисячоліття цей льодовиковий щит повністю зникне, що призведе до підвищення рівня вітового оке ну н 7 м. рив тиме т кож термічне розширення вод вітового оке ну. одо нт рктиди, то клім т т м н стільки холодний, що в р зі глоб льного потепління, з д ними , м с льодовикового щит не лише не зменшиться, й зросте через збільшення кількості оп дів. роте не виключено, що глоб льне потепління призведе до посунення льодовикових щитів т н віть сповз ння хідно нт рктичного льодовикового щит до оке ну, що спричинить суттєве збільшення рівня вітового оке ну пон д прогнозов ні зн чення.

н слідок прогнозов ного збільшення рівня морів кр їн може з зн ти зн чних збитків т витр т. прикл д, очікув не до кінця століття підвищення рівня орного т зовського морів н 22 см зумовить потребу підсилення берегоукріплюв льних робіт, 
3 г льну в ртість яких оцінюють у пон д 1,2 млрд дол. е більше підняття рівня моря, яке прогнозують з несприятливими сцен ріями, може призвести до дегр д ції дельт ун ю, ніпр , ністр , знищення тисяч гект рів земельного фонду т $з$ топлення десятків тисяч гект рів низинних ділянок узбережжя [2].

лоб льне потепління м тиме нег тивний вплив н екосистему орного моря. ідвищення зимових темпер тур сприяє посл бленню процесу перемішув ння, яке відбув ється щозими з вдяки опуск нню щільнішої води, охолодженої біля поверхні моря.

цьому р зі зменшується н сичення киснем глибинних вод. д ними нституту окенології осійської к демії н ук, з ост нні дв десятиліття меж сірководневого ш ру підвищил сь м йже н 12 м, тобто потужність ш ру, н сиченого киснем, зменшил сь н $10 \%$. м йбутньому цей процес може посилитись, що суттєво змінить екосистему моря.

віть 3 незн чних змін середніх зн чень клім тичних пок зників зміни в х $\mathrm{p}$ ктері глоб льних тмосферних процесів можуть призвести до зрост ння повторюв ності т інтенсивності низки стихійних і к т строфічних метеорологічних явищ. с мперед, підвищення темпер тури тмосферного повітря т поверхні вітового оке ну спричинить зрост ння енергії синоптичних вихорів т збільшення вологомісткості повітря, що, відповідно, сприятиме збільшенню м ксим льних кількостей оп дів, які вип д ють під ч с потужних циклонів т є причиною к т строфічних повеней.

ких же клім тичних змін треб очікув ти в кр їні впродовж м йбутніх десятиліть? посередков ну інформ цію про м йбутні зміни клім ту може д ти н ліз змін, які м ли місце відбулися ост ннього століття. кщо припустити, що зміни зумовлені н с мперед дією нтропогенного чинник, то можн спрогнозув ти, що в м йбутньому з г льний тренд змін збережеться 3 можливого посилення їхньої інтенсивності. д ними скл деного німецькими ф хівцями тл су клім тичних змін у вропі впродовж 1891-1990 рр. б чимо т ке: у з хідних регіон х кр їни з з зн чений період не спостеріг ли суттєвих змін у середніх річних темпер тур х повітря т кількостях оп дів, н томість н північному сході держ ви середньорічні темпер тури підвищились н $1^{\circ}$, річні кількості оп дів збільшились н 100 мм [6]. роте не менш в жливими є й сезонні в рі ції цих змін. прикл д, н території ольщі впродовж 1981-2000 pр., порівняно з 1951-1980 рр. суттєво (н 0,8-1,5 ${ }^{\circ}$ ) підвищилися темпер тури січня-тр вня, тоді як для решти семи місяців року темпер турні зміни були незн чними. [5]. кі зміни дост тні для того, щоби вплинути н біотичні х р ктеристики т процеси у л ндш фт х. окрем, польські дослідники припуск ють, що, оскільки с ме весн є поч тком вегет ції рослин т гніздув ння пт хів, підвищення весняних темпер тур є головним чинником суттєвого зрост ння 3 з зн чений період кількості пт хів т зміни хвойних деревост нів листяними у іловезький ущі [7].

и про н лізув ли дві серії клім тичних д них, отрим них шляхом опр цюв ння результ тів спостережень н метеост нціях 3 хідних регіонів кр їни: перш серія д них охоплює період 1881-1935 рр. [3], друг - 1975-1995 pp. [1]. сього про н лізов но д ні 19 метеост нцій н території олинської, івненської, ьвівської, в нор нківської, ернопільської, мельницької, к рп тської т ернівецької обл стей. міни термічного режиму між цими період ми обчислені шляхом віднім ння середньомісячних д них для першого періоду від д них для другого.

ереднє зн чення підвищення приземної темпер тури повітря з метеост нціями ст новило близько $0,5^{\circ}$, що цілком узгоджується з д ними те виявлен зн чн неоднорідність процесу потепління як у геопросторовому спекті, 
т к і в розрізі сезонів року. темпер тури з фіксов но н ередк рп тті $\left(0,1-0,45^{\circ}\right)$.

прикл д, н йбільші зн чення підвищення середньорічної оліссі $\left(0,6-0,9^{\circ}\right)$, н йменші - н оділлі т у хідному поч тку весни: н всіх метеост нціях підвищення середньої темпер тури січня перевищило $1^{\circ}$, н метеост нціях олині т ередк рп ття - н віть $2^{\circ}$. ля періоду 3 тр вня по листоп д зміни темпер тур були незн чними, в липні н 17 метеост нціях $з$ 19 з фіксов не н віть невелике зниження середньомісячних темпер тур (у середньому н $0,45^{\circ}$, рис. 3$)$.

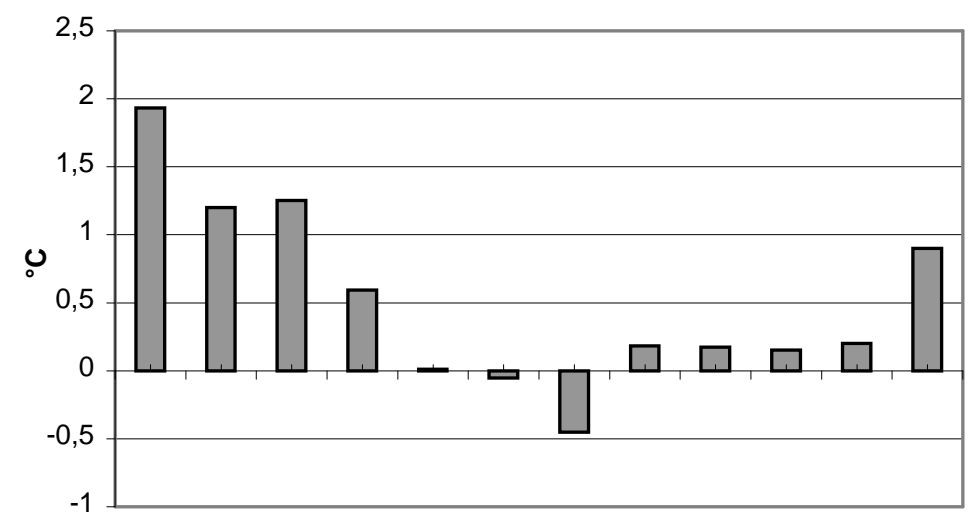

ис. 3. міни середньомісячних приземних темпер тур повітря між період ми 1881-1935 т 1975-1995 pp., у середньому з 19 метеост нціями з ходу кр їни.

тже, н підст ві отрим них д них можн спрогнозув ти ймовірні м йбутні зміни темпер турного режиму з хідних регіонів кр їни вн слідок впливу глоб льного потепління. прикл д, не треб очікув ти суттєвого збільшення суми ктивних темпер тур 3 вегет ційний період, отже, - поліпшення умов вирощув ння теплолюбних культур. іншого боку, зменшиться потреб в енергоносіях для оп лення т з'явиться можливість скорочення трив лості оп люв льного сезону н весні. отрібно очікув ти скорочення трив лості т зменшення стійкості льодост ву н річк х т озер х. більшення повторюв ності відлиг призведе до зрост ння ризику зимових п водків н piчк х. дноч сно погірш ться умови для зимового туризму в рп т х. ет льніший прогноз, зокрем стосовно впливу клім тичних змін н екосистеми, неможливий без одноч сного вр хув ння можливих змін кількості т режиму тмосферних оп дів i деяких інших клім тичних х р ктеристик.

1. ін $и$., урн $е в$. емпер турний режим повітря і грунту в кр їні. ьвів: ид-во н ук.техн. л-ри, 2001. 800 с.

2. ерг . кр їн н шляху до іото: прогрес чи регрес? // овнішні спр ви. 2009. № 1.

3. пр вление гидрометеорологической службы . лим тологический спр вочник ып. 10 по кр. и олд. . иев, 1950. 
4. Climate Change 2007: Synthesis Report / An Assessment of the Intergovernmental Panel on Climate Change, adopted section by section at IPCC Plenary XXVII (Valencia, Spain, 12-17 November 2007) // http://www.ipcc.ch/pdf/assessment-report/ar4/syr/ar4_syr.pdf

5. Kozuchowski K. Some aspects of the contemporary climatic changes in Poland // Man and climate in the $20^{\text {th }}$ century / Studia geogr. Wroclaw, 2003. N 75. P. 67-77.

6. Schonwiese C.-D., Rapp J., Fuchs T., Denhard M., 1993. Klimatrend-Atlas Europa 1891-1990. Ber. 20(4). Frankfurt a. Main: ZUF-Verlag, 1993.

7. Tomialojc L. Implications of climate change for nature conservation // Man and climate in the $20^{\text {th }}$ century: Studia geogr. Wroclaw, 2003. N 75. P. 31-50.

\section{GLOBAL WARMING AND ITS INFLUENCE ON THE THERMIC REGIME OF WESTERN UKRAINE}

\section{O. Mkrtchian}

Ivan Franko National University of Lviv, . Doroshenko St., 41, UA - 79000 Lviv, Ukraine

The newest scientific data on size, causes, factors, and prognosis for global warming are analyzed based on the last IPCC report. The comparative analysis of meteodata for the Western Ukraine is given, that allowed to reveal the main trends of changes in temperature regime for the last century. This allowed formulating a general prognosis of the temperature changes for the next decades, as well as their consequences for nature and economy.

Key words: global warming, greenhouse effect, temperature regime, climate changes prediction.

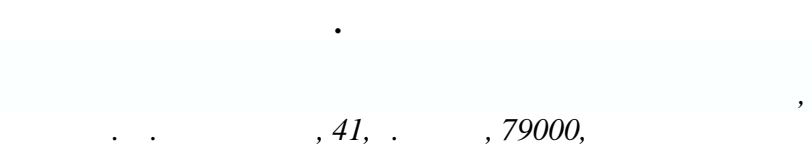

ро н лизиров но новейшую н учную информ цю о р змер х, причин х, ф ктор х и прогноз х глоб льного потепления н основе д нных последнего докл д ежпр вительственной группы экспертов по вопрос м изменений клим т. основе ср внительного н лиз д нных н блюдений метеост нций з п дных регионов кр ины выявлено основные тенденции изменения темпер турного режим приземного слоя воздух з последнее столетие. дел н обобщенный прогноз изменений темпер турного режим в последующие десятилетия и вероятных последствий этих изменений для природы и хозяйств .

лючевые слов : глоб льное потепление, п рниковый эффект, темпер турный режим, прогноз клим тических изменений.

т ття н дійшл до редколегії 02.04.2009 рийнят до друку 20.09.2009 